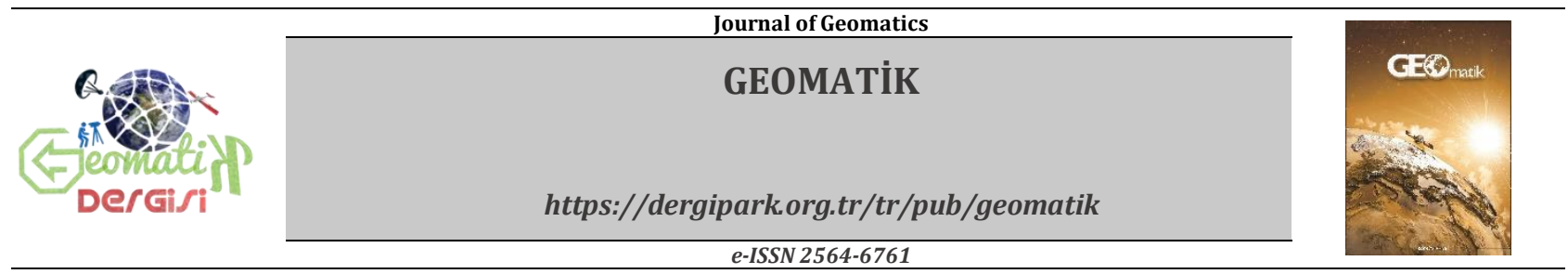

\title{
6306 sayılı Kanun Kapsamında Yapısal Değişiminin Yıllara Göre Elektrik Tüketim Boyutuyla İncelenmesi: Uşak İli Örneği
}

\author{
Fatih Taktak*1, Mehmet Ilı² \\ ${ }^{1}$ Uşak Üniversitesi, Mühendislik Fakültesi, Harita Mühendisliği Bölümü, Uşak, Türkiye \\ ${ }^{2}$ OEDAŞ, Harita Mühendisi, Ușak, Türkiye
}

\author{
Anahtar Kelimeler \\ 6306 sayll kanun \\ Kentsel yenileme \\ Elektrik enerjisi tüketimi \\ Konumsal veri analiz
}

\begin{abstract}
ÖZ
Son dönemlerde dünyada olduğu gibi Türkiye'de de gündemin önemli maddelerinden biri kentsel dönüşüm olgusudur. Ülkemizde 1950 yılından itibaren kanuni düzenlemelerde yeri olan kentsel dönüşüm konusu, 2012 yılında yürürlüğe giren "6306 sayılı Afet Riski Altındaki Alanların Dönüştürülmesi" kanunuyla odak noktası haline gelmiştir. Bu kanun çerçevesinde, Uşak ili merkezde uygulamaya konulan kentsel yenileme sonucunda riskli yapılar (kerpiç, ahșap veya kagir yapılar vb.) yıkılarak yerine daha modern ve bölge ihtiyaçlarına uygun ( İmar planına uygun konut veya apart daireler vb.) konutlar yapılmıştır. Eski yapıların genellikle tek katlı ya da 2 katlı (1-2 daireli) olması nedeniyle konum bașına elektrik tüketimi daha az olarak gerçekleșmiștir. 6306 sayılı kanunun çıkışından önce ve sonraki dönemi kapsayan 2009-2016 yılları arasına bakıldığında, imar durumuna göre yapılan yeni yapılar 3-5 katlı daire ya da apart daire şeklinde bitişik nizamdır. Bu sebeple, konumsal olarak bağımsız daire ve kişi sayısındaki artışında etkisiyle elektrik enerjisi tüketimindeki değişim ilgili yıllarda dikkat çekici bir oranda yükselişe geçmiştir. Bu çalışmada, konumsal veri analizi yapılarak Uşak ilinde 2009-2016 yılları arasında ekonomik ömrünü tamamlamış olan eski binaların yıkılarak geneli bitișik nizam imar düzenine sahip ve dikey konut yapılanmasının hızlı bir șekilde gerçekleștiği Ünalan Mahallesindeki konut başına elektrik tüketim yoğunluğu ve değişimi belirlenmiştir.
\end{abstract}

\section{Investigation of Structure Changes in the Scope of Law No. 6306 by Electricity Consumption According to Years: An Example of Ușak}

\author{
Keywords \\ Law no. 6306 \\ Urban renewal \\ Electricity consumption \\ Spatial data analysis
}

\begin{abstract}
As one of the key ingredients in the world in recent years in Turkey's agenda is urban renewal cases. The subject of urban transformation, which has a place in the legal regulations since 1950, has become the focal point with the Law No. 6306, which came into force in 2012. Within the framework of this law, as a result of the urban transformation implemented at Uşak center, risky structures (adobe, wood or masonry structures, etc.) were demolished and replaced with modern and residential buildings. Due to the fact that the old buildings were usually single-storey or 2-storey, electricity consumption was less used in the spatial dimension. But before and after the exit of Law No. 6306; When looking between 2010 and 2016, new buildings constructed according to the zoning status have taken the form of a 3-5-storey apartment or apart-shaped apartment. Thus, the change in electricity consumption, positively due to the increase in the number of apartments and the number of people, has increased considerably between the relevant years. In this study; In the city of Ușak, between 2010 and 2016, the Unalan quarter, which has a complex zoning order and completed its economic life, has been investigated. According to the density of electricity consumption, the change in years has been realized by Geographical Information System (GIS) and spatial data analysis.
\end{abstract}




\section{GÍRIŞ}

6306 sayılı kanun ile, afet riski altındaki, ekonomik ömrünü doldurmuş bulunan alanların, gerekli tüm kentsel ve sosyal fonksiyonlarının yenilenerek fiziki ve konumsal özelliklerinden kaynaklanan olası tüm doğal afet riskleri de ortadan kaldırılacak biçimde yeniden yapılması hedeflenmektedir. Dönüşüm biçimlerine bakıldığında, genellikle yenilemenin ön plana çıktığı uygulamaların desteklendiği görülmektedir. Genel olarak kentsel yenileme, üst-orta sınıfların, kentin içinde bulunan ve süreç içinde çeşitli ekonomik, siyasal ve toplum koşulları sonucu çöküntü haline gelmiş alanlardaki yıpranmış konutların gerek bireysel gerekse örgütlü bir yenileme sonucu, bu konutlara yerleşerek yer değiştirmesi süreci olarak ifade edilmiştir (Daşkıran, 2015; Uğur, 2016; Kaplan, 2017).

2012 yılı Mayıs ayı içerisinde yayınlanarak yürürlüğe giren bu kanun, afet riskleri sebepli kentsel dönüşüm uygulamalarını gerçekleştirmek amacı ile düzenlenmiştir. Bu kanun ile dönüşüm faaliyetlerinin gerçekleștirilmesine yönelik olarak ekonomik teşvikler ve yaptırımlar eklenmiştir. İlgili kanunun uygulamalarına ışık tutmak amacı ile 6306 sayılı Kanunun Uygulama Yönetmeliği ve riskli yapıların tespitine yönelik esasları barındıran yönetmeliğin ekleri yayınlanmış, kentsel dönüşüm faaliyetlerini finanse etmek amacıyla "Dönüşüm Projeleri Özel Hesabı" oluşturulmuştur. Bu hesap çerçevesinde gerçekleştirilecek iş ve işlemlere ve harcamalara yönelik "Dönüşüm Projeleri Özel Hesabı Yönetmeliği" yayınlanmış, ayrıca bahse konu özel hesaptan yapılacak kira yardımı ödemelerine yönelik "Kira Yardımı Uygulamaları Kılavuzu" yayınlanmıştır. Burada, 6306 sayılı kanunun dönüşüm faaliyetlerini çok yönlü olarak ele almayı amaçlayan ve kanun kapsamında yapılacak işlemleri hükümlere bağlayarak uygulama bütünlüğü sağlamayı amaçlayan bir düzenleme yapılmıştır (Bentley, 2004; Trencher, 2013; Bilecen, 2015; McPhearson, 2016; Yenice, 2016).

Ülkemizde kentsel dönüşüm ve yenileme süreci, 2012 yılında yürürlüğe giren 6306 sayılı kanununda tanımlanan, “... afet riski altındaki alanlar ile bu alanlar dışındaki riskli yapıların bulunduğu arsa ve arazilerde, fen ve sanat norm ve standartlarına uygun, sağlıklı ve güvenli yașama çevrelerini teșkil etmek üzere iyileștirme, tasfiye ve yenilemeler" olarak belirtilmiştir. Kanunun genel kapsamında, sürecin aktörleri ve yasal çerçeveyi tanımlamakta ve hangi alanlarda kentsel dönüşüm sürecine başvurulması gerektiğine işaret etmektedir. Kanun ile süreçte görev alacak aktörleri; Çevre ve Şehircilik Bakanlığl, idareler (Belediyeler - Büyükşehir ve İlçe Belediyeleri - İl Özel İdareleri) ve TOKI (Toplu Konut İdaresi Bașkanlığı) olarak tanımlamıștır. Anlașıldığı üzere bu kurumlar sürecin kamu bileșenini oluşturmaktadır (Genç, 2008; Aydinli, 2012; Yenice, 2016; Özgür, 2018). Öte taraftan, özel sektör tarafı ise riskli yapı tespitinde Bakanlık tarafından lisanslı kurum ve kuruluşlar ile uygulama sürecini üstlenecek șirketler belirtilmiștir. Üniversitelerin ise bilirkişilik kapsamında, hak sahipleri ile kamu arasındaki uyuşumu kurması amaçlanmıştır (Farías, 2012; Trencher, 2013; e-mevzuat, 2019).

Günümüzün kent planlama çalışmaları, sürdürülebilirlik ilkeleri çerçevesinde gerçekleștirilmesi yadsınamaz bir gerekliliktir. Ekonomik, işlevsel ve görsel olarak yıpranan ve afet riski taşıyan konutların yenilenmesi amacıyla gerçekleştirilen kentsel yenileme çalışmaları da, sürdürülebilir kentsel gelişimin hayata geçirilmesi açısından bir firsat olarak görülmektedir (Turgay, 2018; Parlak, 2018; Kocaoğlu, 2018).

Kentsel yenileme ile mevcut yerleşim yerlerinde ve yeni yerleşim alanlarında alınacak önlemlerin, sürdürülebilirlik açısından eşit derecede öneme sahip, dengeli ve bütüncül bir sistem içerisinde olması amaçlanmıştır. Riskli bina olarak ya da imar adası bazında gerçekleştirilen kentsel yenileme uygulamalarının sürdürülebilir gelişime çözüm olamayacağı açıkça ilgililer tarafından görülmüştür. Ülke çapında verilen kararlar ve bu kararlar doğrultusunda tanımlanan ilkeler ve politikalar, karşılaşılmakta olan problemlerin önüne geçmede önemli rol almıştır. Ancak, bu kısımda unutulmaması gereken, politika ve ilkelerin ölçülebilir olması, bu sayede de denetlenebilir, şeffaf ve değerlendirmeye açık olması gerektiğidir. Buna rağmen, kentsel yenilemeye yönelik politika ve ilkelerin puanlanmasına yönelik performans göstergeleri tanımlanmamış ve bu konuda bir çalışma yapılmamıștır (Kocaoğlu, 2018; Özbek, 2018; Adilhan, 2018; Turgay, 2018).

Enerji, ekonomik büyümenin ve gelişmenin en temel yapı taşlarındandır. Elektrik enerjisi ise, sosyal ve ekonomik altyapının temel unsurlarından birini oluşturan enerji kalemlerinden en esnek yapıda olanlarından biridir. $\mathrm{Bu}$ sebeple gündelik yaşamın her alanında geniş kullanım alanlarına sahip durumdadır. Türkiye'de iktisadi kalkınma ile beraber çeşitli mal ve hizmetlerde tüketim artmaktadır. Bunların bașında ise elektrik enerjisi kullanımı gelmektedir (Kar, 2018; Haliloğlu, 2018; El-Hawary, 2018).

İçinde bulunduğumuz yüzyılda ülkelerin sosyal ve ekonomik alt yapısının ve fiziksel gelișmelerinin en önemli belirleyicisi enerji temini ve tüketimidir. $\mathrm{Bu}$ durum tüketimin ana kaynağı olan ve giderek yükselen kentleşme olgusu ile ilişkilendirildiğinde, kentsel planlama ile enerji ilişkisinin iyi kurgulanması gerektiği ortaya çıkmaktadır. Günümüzde teknolojinin gelişmesiyle birlikte özellikle Avrupa Birliği ülkeleri öncülüğünde gelişen enerji verimliliği teması kent planlarında ve uygulamalarında görülmektedir. Yakın gelecekte kentlerinin 'verimli enerji yönetimi' stratejisine göre biçimlenmesi için, kentsel dönüşüm ve yenileme gerçeği; yerleşme fiziksel planlarının ve yasal zemininin "enerji verimliliği" sistemine göre ele 
alınması gereken konular arasındadır (Uzgören, 2018; Kara, 2018).

Kentsel dönüşümlerde veya yenilemelerde, enerji verimliliği ile maliyetler indirilebilir, yerel istihdam artırılabilir, yerel ve küresel kirlenme azaltılabilir, enerji ihtiyacı düşürülebilir ve sosyal yaşam koşulları düzenlenebilir. Ağırlıklı olarak yapılanma teknolojisi kapsamında değerlendirilen bu potansiyelin çevresel etkilerinin analiz edilerek, kent planlama aşamalarına aktarılması önemlidir. Enerji verimliliği yönünden; kentin gelişimi, yenilenmesi ve sürdürülebilirliği açısından öncelikli konular arasında olması, bu konuların uzmanları tarafından ileri sürülmektedir. (Bozkurt, 2008; Özyurt, 2009; Saatçi, 2013).

Uşak Üniversitesi 2006 yılında kurulmuştur. Üniversitesinde, yıllar içinde artan bölüm sayısı ve kontenjanlardan dolayı öğrenci sayısı her yıl artmaktadır. Üniversite öğrencileri barınma açısından, geçmiş yıllarda yurt sayısının az olması dolayısıly apart dairelere zorunlu bir yönleniş olmuştur. Bu yüzden Uşak ili merkez, apart daire ihtiyacı fazla olan iller arasındadır. Uşak İli merkezde apart daire ihtiyacını karşılayacak uygun mahalle sayısı kısıtlıdır. Konumu ve yapısı itibariyle apart daire yapımına elverişli olan alan "Ünalan Mahallesi" dir. Konut alanı açısından ağırlıklı bitișik nizam ve sıkışmış bir imara sahip olması dolayısıyla yapılan yenilemeler yatayda değil, dikey mimari olarak ilerlemektedir. Ünalan mahallesinde yıllara göre, konutsal sıkışmışlık giderek artmaktadır. Konutsal değişimi görsel olarak anlaşılmasını sağlayacak yöntemlerden biri "Yoğunluk Analizi” yöntemidir. Bu yöntem, 2009-2016 yıllarında elektrik enerjisi tüketiminden faydalanılarak, 6306 sayılı kanunun çıkmış olduğu 2012 yılı itibariyle kentsel yenileme sürecinde, yasanın sunmuş olduğu teşvik ve yaptırımlarla birlikte konut yapı yoğunluğunun artışının, 2012 yılı öncesi ve sonrası değişimi ortaya konulmaya çalışılmıştır.

\section{6306 SAYILI AFET RISKI ALTINDAKI ALANLARIN DÖNÜŞTÜRÜLMESI HAKKINDA KANUN}

Türkiye kentsel dönüşüm ve yenileme ile ilgili; konuyu farklı boyutlarıyla inceleyen, birçok yasal düzenleme hazırlamıştır. 2005 yılındaki 5393 sayılı Belediye Kanunu'nun 73. maddesi ile ilgili belediyeler; konut alanları, sanayi alanları, ticaret alanları, teknoloji parkları, kamu hizmeti alanları, yenileme alanları ve her türlü sosyal donatı alanları oluşturularak, eskiyen kent kısımlarını yeniden inşaası ve restorasyonu yapmak, şehrin tarihi ve kültürel dokusunu korumak veya deprem riskine karşı önlemler almak amacıyla kentsel dönüşüm ve yenileme projeleri uygulanmıştır. Yine 2005 yılında yürürlüğe konulan 5366 sayılı "Yıpranan Tarihi ve Kültürel Taşınmaz Varlıkların Yenilenerek Korunması ve Yaşatılarak Kullanılması Hakkında Kanun", tarihi alan olarak tescil edilen bölgeler ile bu bölgelere ait koruma alanlarının, bölgenin gelişimine uygun olarak yeniden inşa ve restore edilerek, bu alanlarda konut, ticaret, kültür, turizm ve sosyal donatı alanları oluşturulması, tabii afet risklerine karșı önlemler alınması, tarihi ve kültürel tașınmaz varlıkların yenilenerek korunması ve yaşatılarak kullanılmasını amaçlamıştır (Genç, 2008; Çelik, 2013; Kaplan, 2017).

$\mathrm{Bu}$ yasal düzenlemelerin yeterli olamaması, konunun bütünüyle ele alınamaması ve kent problemlerine sürdürülebilir çözümler bulunamaması üzerine, ortaya çıkan doğal afetlerin de yıkıcı sonuçlarından ders çıkarılarak; 2012 yılının mayıs ayı içersinde "6306 Sayılı Afet Riski Altındaki Alanların Dönüştürülmesi Hakkında Kanun” yürürlüğe konulmuştur. Bu kanunun amacl, afet riski altındaki alanlar ile bu alanlar dışındaki riskli yapıların bulunduğu arsa ve arazilerde, fen ve sanat norm ve standartlarına uygun şekilde sağlıklı ve güvenli yaşam çevrelerini teşkil etmek üzere iyileștirme, ayıklama ve yenilemelere dair usul ve esasları belirlemeye çalışmaktır (Daşkıran, 2015; Uğur, 2016; e-mevzuat, 2019).

"6306 sayılı Afet Riski Altındaki Alanların Dönüştürülmesi Hakkında Kanun" ile Kentsel yenileme ülkenin gündemine oturmuştur. Riskli yapıların ve alanların dönüştürülmesi ayrıca bozulan kent dokularının yenilenmesi maksadıyla yerel ve merkezi kurumlar tarafından kentsel dönüşüm ve yenileme uygulamaları yapılmaktadır. Kentsel dönüşüm; kentsel bir alanın fiziksel, çevresel, sosyal ve ekonomik koşullarıyla sürekliliği, iyileștirmesi ve sürdürülebilir olmasına yönelik, çok fonksiyonlu, bir imar uygulaması olarak tanımlanmıştır. (Ülger, 2010; Yomralığlu, 2013).

\section{UYGULAMA}

Geçmişten süregelen bozuk kentleşme, gecekondu ve kaçak yapılaşma, hızlı nüfus artışı, afetlere dayanıksız yapılar, alt yapı ve ulaşım eksikliği gibi sorunlar şehirlerin önemli problemleri arasında görülmektedir. Uzun zamandır plansız gelişen kentlerde, kent çevrelerinin yenilenmesi, riskli yapıların tespit edilerek güvenli konutların yapılması, kentlerdeki sosyal ve tarihi kimliklerin korunarak yenilenmesine olanak tanıyan uygulamaların gerçekleştirilmesi amaçlanmalıdır. Kentsel yenileme uygulamaları, mülkiyeti içine alan ve mülkiyete anlam katan önemli uygulamalar olduğu için şeffaf, anlașlabilir ve kentsel dönüșümün "tüm disiplinler" tarafından kabul edilebilir olmalıdır.

Riskli yapıların yenilenmesinin, kent planına kattığı değişimin tespit edilmesi öncelikli durumlar arasında olması kaçınılmazdır. Kentin konut değişiminin, ilgili aktörlerin mevcut enerji tüketiminin yıllara göre değișiminden de ortaya çıkarılabileceği düşünülmüş ve bu kapsamda bir çalışma gerçekleştirilmiştir.

Bu duruma yönelik olarak, Uşak kentinde (Şekil 1), yapılanma hareketliliğinin en fazla olduğu mahalleler arasından, Uşak Belediyesinin ilgili 
birimlerinden elde edilen veriler ışığında, Uşak'ın eski yerleşim yerlerinden biri olan ve yapısal değişimin en fazla yaşandığı "Ünalan Mahallesi" çalışma alanı olarak seçilmiștir.

Uşak ili yeni Üniversite kentlerinden biri olması dolayısıyla, apart daire ihtiyacı çok fazla olan illerden birtanesidir. Apart daire ihtiyacını gidermeye çalışan bir konumda olan Ünalan mahallesinde; konut alanı açısından sıkıșmış bir yapıya sahip olması ve şartları kısıtlı olması dolayısıyla yapılan yenilemeler imar açısından yatayda değil, dikey mimari olarak ilerlemektedir. 16.05.2012 tarih ve 6306 sayılı Afet Riski Altındaki Alanların Dönüştürülmesi Hakkında Kanunun çlkmasından 4 yıl öncesi ve 4 yıl sonrasıyla ilgili; 2009-2016 yıllarını kapsayan bir çalışmadır. İncelemeyle Ünalan mahallesindeki yenileme değişimi, her binaya ait bağımsız bölümün elektrik abonesinin elektrik enerjisi tüketiminden tespit edilmeye çalışılmıştır (Şekil 2).

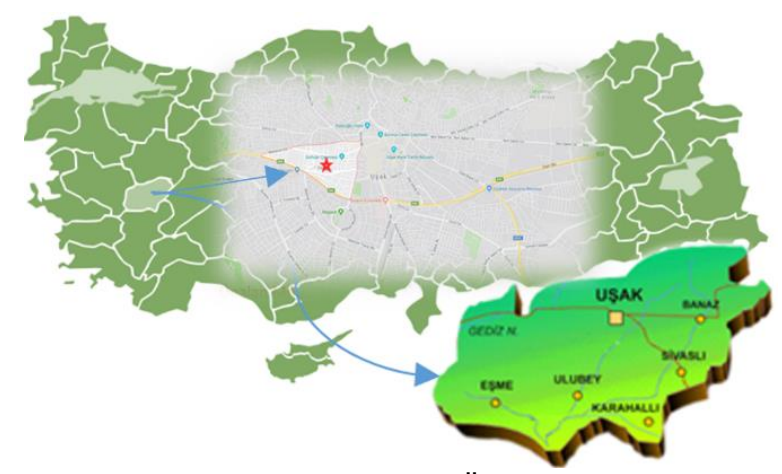

Şekil 1. Uşak ili Merkez Ünalan Mahallesi'nin Konumu ve Bölge, Sinır Durumu

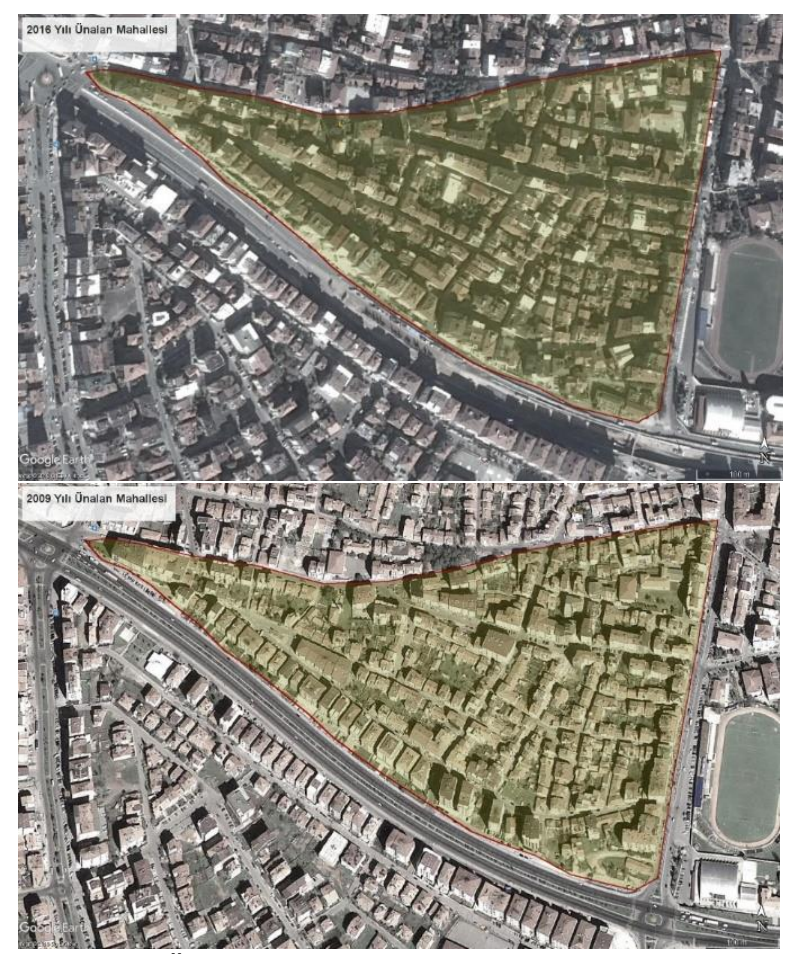

Şekil 2. Ünalan Mahalesinin 2009 ve 2016 Yılları Uydu Görüntüsü (Landsat 8 Uydusu)
Yıllara göre abonelik bazında elektrik enerjisi tüketimi verileri, 2009-2016 yılları arası Uşak ili Osmangazi Elektrik Dağıtım AȘ. (OEDAȘ) kurumundan elde edilmiştir. Elde edilen verilerin değerlendirilmesi ışı̆̆ında, 2009 ile 2016 yılları içerisinde, 1835 abonenin tüketici olarak kayıt olduğu tespiti yapılmıştır. Tüm abonelerin yıllara göre toplam tüketim değerleri Şekil 3'te ve abonelikler açısından yıllara göre tüketim verileri de Şekil 4'de verilmiştir. Bazı bağımsız bölüm abonelerinin yıllara göre yıllık elektrik enerjisi tüketimi verileri kW (kilowatt) bazında Tablo 1'de verilmiştir. Tabloda; sarı renkle belirtilmiş olan yerlerde o dönemlerde; abonelik bazında tüketimin olmadığı ayrıca yeni aboneliklerin alınması dolayısıyla, yeni konutların yapıldığı anlaşılmaktadır.

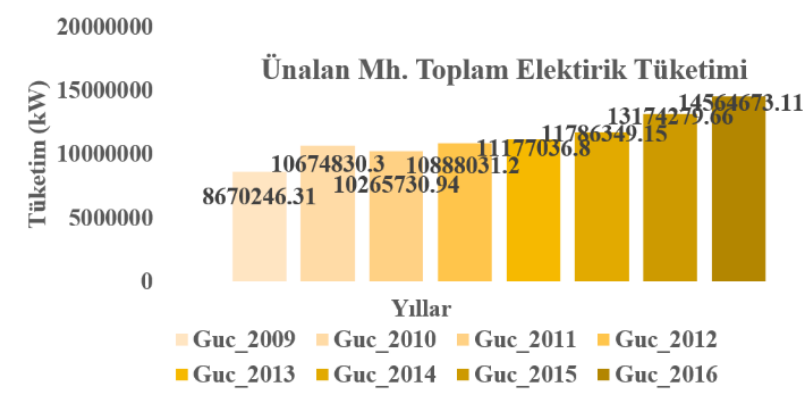

Şekil 3. Ylllara Göre Ünalan Mahallesindeki Elektrik Enerjisi Tüketimi

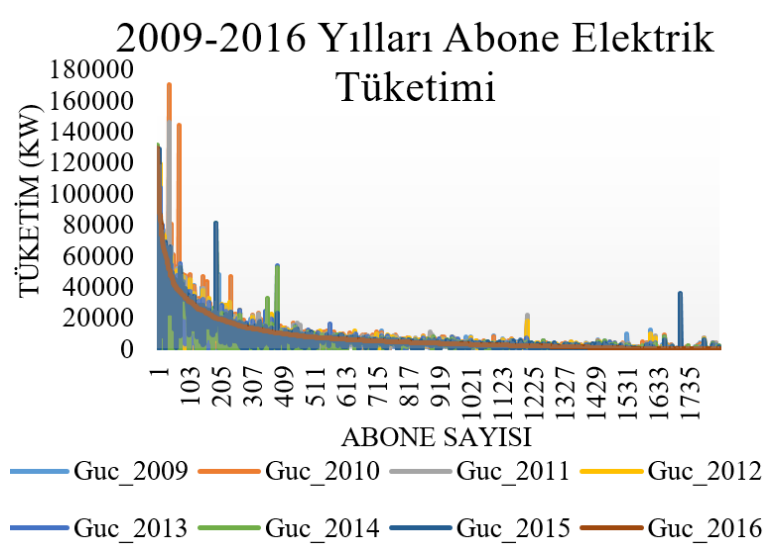

Şekil 4. Yıllara Göre Ünalan Mahallesi'ndeki Abonelerin Elektrik Enerjisi Tüketimi

Ünalan Mahallesi'ndeki konut üzerindeki yapısal değișimin kanıtı olarak, Ușak Belediyesinin ilgili birimlerinden binaların eski hali ve yeni hali olarak görüntüleri elde edilmiştir (Şekil 5). Şekil 5'te eski hali 1a'ya bakıldığında eski halinin 3 katlı olduğu görülmekteyken, yeni hali 1b' ye bakıldığında kat adeti bir değer artarak 4 katlı hale gelmiştir. Aynı şekilde eski hali 2a' ya bakıldığında, 1 katlı müstakil bir bina olarak görülmekteyken, yeni hali $2 b^{\prime}$ de garajı ile birlikte 3 kata çıktğı ve apart daire tarzı şekilde yapıldığı görülmektedir. Ünalan mahallesi için bu örnekleri çoğaltmak, mümkündür. 


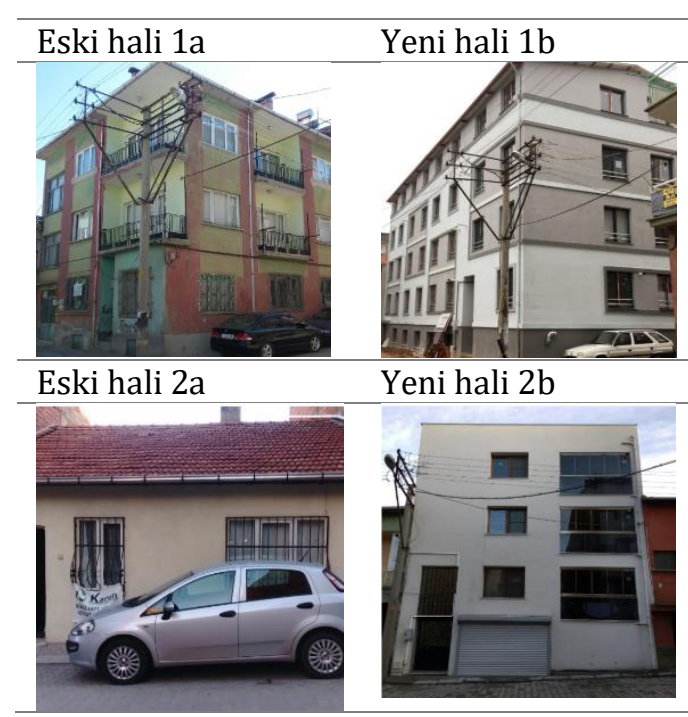

Şekil 5. Ünalan Mahalesi'nde Mevcut Binaların Eski ve Yeni hali

\subsection{Materyal ve Yöntem}

Çalışmada kullanılmak üzere, Ünalan Mahallesi'ndeki (16.6 ha büyüklüğündeki alan) elektrik enerjisi kullanan aboneliklerin yıllara göre elektrik tüketim verileri OEDAŞ kurumundan alınmıştır. Abone elektrik enerjisi tüketim verileri düzenlenmiş ve araştırma doğrultusunda kullanılabilecek veriler haline getirilmiștir. Coğrafi Bilgi Sistemi (CBS) yazilımlarından ArcGIS 10.5 kullanılarak Ünalan mahallesindeki abonelerin bina başına düşen elektrik tüketim verileri ile ilişkilendirilmiştir. Mahalle verisindeki tüketim değerleri doğrultusunda veri tabanı oluşturulmuş ve analiz gerçekleştirilmiştir. Yıllara göre mahalledeki bölgesel değişimin anlaşılması için yoğunluk bölgelerinin tespiti gerekmektedir. Yoğunluk fonksiyonu noktalardan oluşan bir katmandan, noktaların ağırlıklarına göre matematiksel bir model kullanarak, sürekli bir yüzey üretilmesi amaçlanmaktadır. Yoğunluk Analizi ile nokta ve çizgi tipi özelliklerin kümelendiği yerler belirlenebilmektedir. Kümeleme çalışmasında üç farklı kümelenme incelenmektedir. Kümele çalışmaları için bu boyutların incelenmesinde genellikle yoğunluk analizi kavramı kullanılır. CBS'de konumsal yoğunluk analizi (spatial analysis) çalışmaları bilindiği gibi üç kısımda luşmaktadır, bunlar; Noktasal, Çizgisel ve Kernel yoğunluk analizidir (Illian, 2008; Yalçın, 2013; Rawluk, 2019).

Araştırmamızda; konut değişimi noktasal bazlı (Şekil 8'de 2009 nolu haritada noktasal abone konumlarının görünümü) bakıldığı için, çalışmaya uygun yöntem "noktasal yoğunluk analizi" kullanılmıştır (Şekil 6). Nokta yoğunluk analizi, ayrık noktalarla ifade edilen verilerin analizi ile noktalardan yoğunluk yüzeyi oluşturmaktadır. Nokta desenleri analiz edilirken, temel olarak tam konumsal rassallık (tesadüfilik) hipotezine karşıllk noktaların kümelenme ve düzenlilik durumunu belirtmektedir. Noktasal yoğunluk analizi her bir pikselde ya da tanımlı bir hücre içerisine düşen noktaların sayısı ile değerlendirilerek hesaplanmaktadır. Analiz değerleri, her bir pikselde ya da tanımlı bir hücre içerisine düşen noktaların sayısı ile değerlendirilerek $\mathrm{kW} / \mathrm{m}^{2}$ olarak hesaplanmıştır (ArcGIS for Desktop, 2019; Netcad Portal, 2019). 8 ylllık abonelerin tüketim verileri yardımıyla yoğunluk analizi yapılmış ve elde edilen veriler ışı̆̆ında 2009 ile 2016 yılları arası elektrik enerjisi tüketim değişimi belirlenmiştir (Şekil 8).

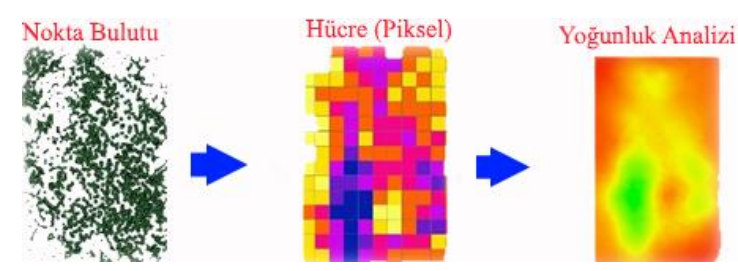

Şekil 6. Noktasal Yoğunluk Analizi Aşamaları

Tablo 1. Yıllara Göre Ünalan Mahallesi'ndeki Bazı Abonelerin Elektrik Enerjisi Tüketimi verileri (kW)

\begin{tabular}{|c|c|c|c|c|c|c|c|c|}
\hline z Z & $\begin{array}{l}\text { No } \\
\text { ठิ }\end{array}$ & $\begin{array}{l}\text { No } \\
\stackrel{0}{0}\end{array}$ & $\begin{array}{l}\text { No } \\
\text { 田 }\end{array}$ & $\underset{N}{\stackrel{N}{N}}$ & $\underset{\stackrel{N}{\omega}}{\stackrel{N}{\omega}}$ & 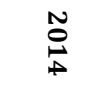 & $\begin{array}{l}\text { No } \\
\stackrel{\text { v }}{*}\end{array}$ & 吕 \\
\hline 77376 & 1113 & 1186 & 938 & 45 & 0 & 0 & 119 & 351 \\
\hline 2010 & 0 & 0 & 1152 & 734 & 1044 & 2075 & 2330 & 46 \\
\hline 68990 & 283 & 299 & 291 & 301 & 333 & 299 & 317 & 337 \\
\hline 69365 & 0 & 0 & 0 & 0 & 0 & 0 & $\mathbf{0}$ & 330.2 \\
\hline 75928 & 1185 & 1427 & 1808 & 1572 & 1779 & 120 & 19 & 311 \\
\hline 33146 & 139 & 230 & 357 & 417 & 332 & 433 & 368.75 & 308.97 \\
\hline 46307 & 0 & 0 & 214 & 539 & 678 & 834.73 & 483.32 & 301.66 \\
\hline 75422 & 661 & 807 & 1045 & 979 & 1062 & 1078 & 811 & 288.83 \\
\hline 2041 & 3084 & 3552 & 3081 & 1292 & 1173 & 852.29 & 679.24 & 285 \\
\hline 78533 & 705 & 1558 & 364 & 165 & 35 & 108 & 320 & 272 \\
\hline$*$ & * & $*$ & $*$ & $*$ & $*$ & $*$ & $*$ & * \\
\hline
\end{tabular}

Ünalan mahallesinin yllara göre elektrik tüketim yoğunluk analizi karşılaştıracak olunursa, Şekil 8'e bakıldığında;

- Elektrik enerjisi tüketimi, yeşilden kırmızıya giden renk skalasına göre yıllar içinde tüketimin artığı görsel haritalardan anlaşılmaktadır.

- Haritalardaki renk skalalarına bakıldığında tüketim yoğunluğuna göre ara değerler oluşturulmuştur. Burdan yola çıarak ilgili haritalarda, renksel yoğunluğa göre belirli alanlarda elektrik tüketiminin arttığından yola çıkarak afet riski altındaki eski konutların yenilendiği anlaşılmaktadır.

- $\quad 2010$ yılı harita görüntüsüne bakıldığında güney-doğu kesiminde, diğer yıllara göre bir bölgenin kırmızı olduğu görülmektedir. İlgili bölgede elektrik tüketimini fazlalaștıran durumun "İş̧aat Elektriği" o dönem fazla kullanılmış olabileceği OEDAŞ uzmanları tarafından belirtilmiştir.

- $\quad$ Elektrik tüketim artışının güney-doğu kesim olan, Uşak-İzmir karayoluna paralel kısımda olduğu varsayımından konut artışının o bölgede yoğunlaştığı anlaşılmıştır.

- 2019-2016 yılları arası tüm haritalara bakıldığında, değişimin yaşanmadığı belirli kısımların devletin tasarrufu altında veya park 
alanları olduğu ve o bölgelerde o yıllar arası

sahadan alınan bilgilerle (Şekil 2) anlaşılmıştır.

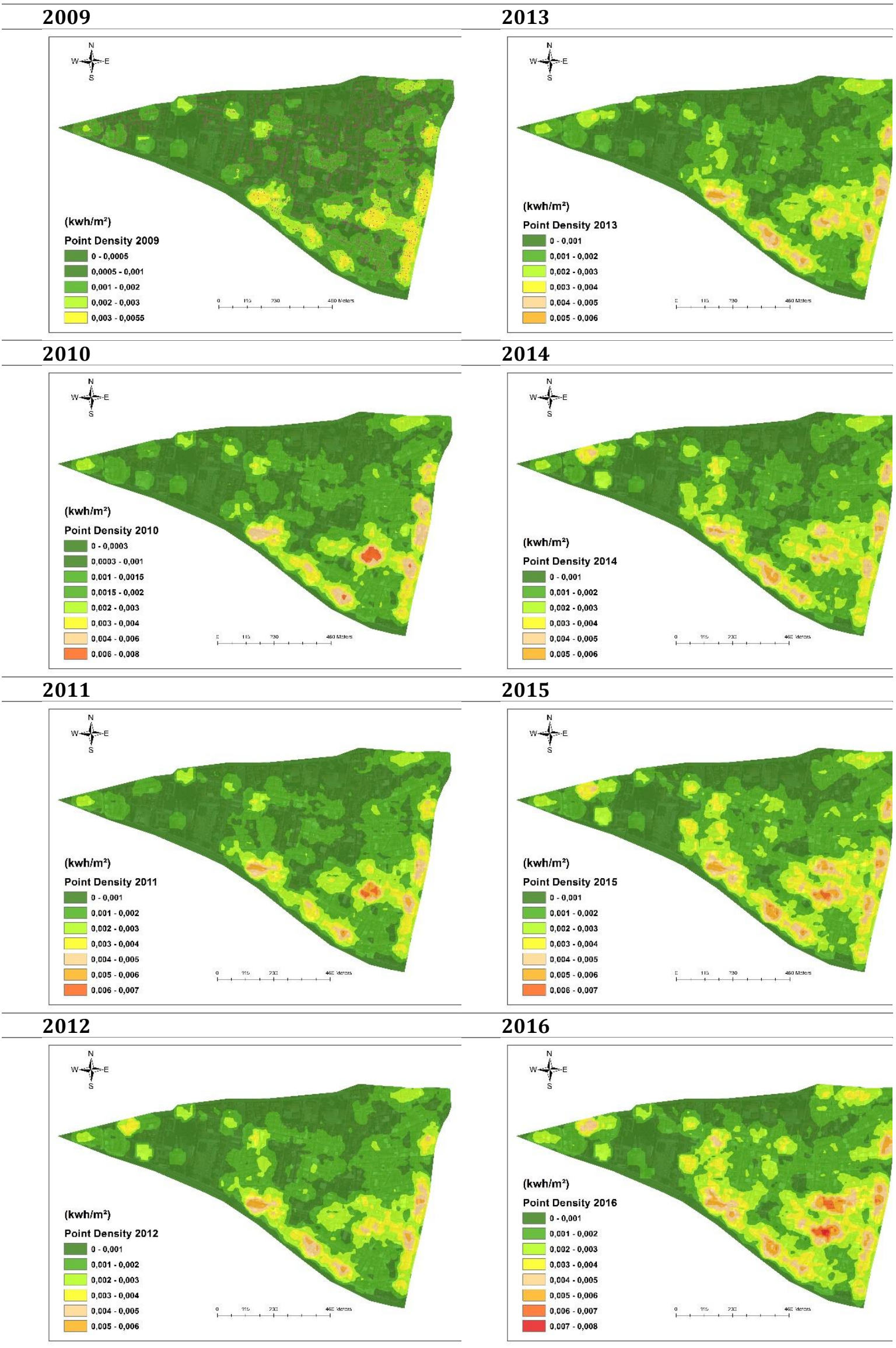

Şekil 8. Ünalan Mahallesi'nin Yıllara göre Elektrik TüketimYoğunluk Analizi Karşıllaştırma Haritaları değişimin az olduğu uydu görüntülerinden ve 
Kentsel dönüşümlerde veya yenilemelerde "enerji verimliliği önlemleri" ile maliyetler azaltılabilir, yerel istihdam artırılabilir, yerel ve küresel bazda kirlilik azaltılabilir, enerji bağımlılığı düşürülebilir ve sosyal yaşam olanakları iyileştirilebilir. Ağırlıklı olarak inşaat ve yapı teknolojisi kapsamında değerlendirilen bu potansiyelin çevresel etkilerinin tahlil edilerek, kentsel planlama süreçlerine aktarılması önem arz etmektedir. Enerji verimliliği açısından, kentin gelişimi, yenilenmesi ve sürdürülebilirliği açısından öncelikli konular arasında olmalıdır.

Özetlenirse; Uşak ili, merkez Ünalan Mahallesindeki, yapısal değişimin ana nedenleri ve sonuçları sıralanacak olursa;

- $\quad$ Uşak ilindeki mevcut Uşak Üniversitesinin 2006 yılında kurulan yeni bir üniversite olması ve gelişime açık olması dolayısıyla öğrenci sayısındaki yıllara göre artışın barınma açısından; kent merkezindeki yurt sayısının azlığı nedeniyle, konut ihtiyacının artmasıdır. Bu nedenle ilgili mahallede öğrenciye yönelik apart daire tarzı bina sayısı artışı elektrik enerjisi tüketiminin artışı açısından en önde gelen nedenlerden biri olduğu Şekil 8'e bakıldığında anlaşılmaktadır.

- Ünalan mahallenin konum olarak Uşak merkeze yakın olması ve burada yaşayan vatandaşların veya öğrencilerin merkezdeki ihtiyaçlarını yürüme mesafesinde giderme ihtiyacından dolayı bu alana yerleşme oranının yıllara göre artış göstermesidir.

- Ünalan mahallesinin geneli itibarıla imar planı açısından ağırlıklı bitişik nizam olmasından dolayı araştırmalarda arsa taşınmaz değerlerinin, $\mathrm{m}^{2}$ bazında arsaların küçük olması dolayısıyla maliyetinin daha uygun olmasıdır.

- $\quad$ Yatay mimari değil, dikey mimari akımının artması dolayısıyla, bağımsız bölüm sayısının çoğalmasıdır.

- Ş̧ehir içi ulaşım araçları açısından da güzergah olarak, Ünalan Mahallesinin konumuna yakın yerlerden geçmesi de bu alana yerleşme oranının yıllara göre artış göstermesinde etkin nedenlerden bir tanesidir.

- CCalışma alanına bakıldığında; kentin gelişimi, yenilenmesi ve sürdürülebilirliği açısından belirli önlemlerin alınmadığı anlaşılmaktadır.

- 2009-2016 Yllları arası elektrik enerjisi tüketimi, konut sayısının artması veya kat yükselmesi sebebiyle enerji verimliliği açısından önlem alınmadığı için enerji tüketimin artığı söylenebilir.

Günümüzde yapılacak projelerde Çevre Şehircilik Bakanlığının da önemle üzerinde durduğu; Mekansal (konumsal) planlama ve uygulama çalışmalarının şehirlerin kimliğini canlandıran, yatay mimariyi esas alarak mahalle ve sokak kavramını öne çıkaran bir şehircilik anlayışıyla yürütülmesi gereklidir. 


\section{BILLGILENDİRME/TEŞEKKÜR}

Çalışmaya; verilerini vererek destek sağlayan OEDAŞ kurumuna teșekkür ederiz.

\section{KAYNAKÇA}

Adilhan, Ö. ve Ünverdi, L. (2018). Kentsel Yenileme Sürecinde Kentsel Tasarımın Önemi: AydınSöke Örneği. Adnan Menderes Üniversitesi Sosyal Bilimler Enstitüsü Dergisi, 5(1), 226-261.

ArcGIS for Desktop. (5.07.2019). Erişim adresi http://desktop.arcgis.com/en/arcmap/10.3/to ols/spatial-analyst-toolbox/how-point-densityworks.htm

Aydinli, H. I. ve Turan, H. (2012). Kuramsal ve yasal çerçevede Türkiye'de kentsel dönüşüm. Selçuk Üniversitesi Sosyal Bilimler Enstitüsü Dergisi, (28), 61-70.

Bentley, I. (2004). Urban transformations: Power, people and urban design. Routledge.

Bilecen, T. (2015). Yeni Afet Yasasında Hukuksal ve Demokratik Esneklik. Anadolu Üniversitesi Sosyal Bilimler Dergisi, 15(3), 145-158.

Bozkurt, A. U. (2008). Yenilenebilir enerji kaynaklarının enerji verimliliği açısından değerlendirilmesi. (Doctoral dissertation), DEÜ Sosyal Bilimleri Enstitüsü.

Çelik, A. (2013). Yerel Özerklik Açısından 5393 Sayılı Belediye Kanunu'nun Genel Bir Değerlendirilmesi. Süleyman Demirel Üniversitesi İktisadi ve İdari Bilimler Fakültesi Dergisi, 18(1), 17-28.

Daşkıran, F. ve Ak, D. (2015). 6306 Sayılı Kanun Kapsamında Kentsel Dönüşüm. Yönetim ve Ekonomi Araştırmaları Dergisi, 13(3), 264-268.

El-Hawary, M. E. (2018). Electrical energy systems. Crc Press.

e-mevzuat (6306 Sayili Kanunun Uygulama Yönetmeliği). (03.04.2019). Erişim adresi http://www.mevzuat.gov.tr/Metin.Aspx?Mevz uatKod=7.5.16849\&Mevzuatlliski $=0 \&$ sourceX mlSearch $=6306 \% 20$ SAYILI

Farías, I. ve Bender, T. (Eds.). (2012). Urban assemblages: How actor-network theory changes urban studies. Routledge.

Genç, F. N. (2008). Türkiye'de kentsel dönüşüm: Mevzuat ve uygulamaların genel görünümü. Yönetim ve Ekonomi: Celal Bayar Üniversitesi İktisadi ve İdari Bilimler Fakültesi Dergisi, 15(1), 115-130.
Haliloğlu, E. Y. ve Tutu B., E. (2018). Türkiye İçin Kısa Vadeli Elektrik Enerjisi Talep Tahmini. Journal of Yasar University, 13, 51.

Illian, J., Penttinen, A., Stoyan, H., ve Stoyan, D. (2008). Statistical analysis and modelling of spatial point patterns (Vol. 70). John Wiley \& Sons

Kar, M., Ağır, H., Türkmen, S. (2018). Gelișmekte Olan Ülkelerde Elektrik Tüketimi ile Ekonomik Büyüme İlişkisinin Ekonometrik Tahmini. ICPESS 2018 PROCEEDINGS Volume 2: Economic Studies, 305.

Kara, M. A., ve Ciğerlioğlu, O. (2018). Türkiye'de İl Düzeyinde Elektrik Tüketimi ile GSYIH Arasındaki İlişkinin Mekânsal Analizi. ICPESS 2018 PROCEEDINGS, Volume 2: Economic Studies, 269.

Kaplan, O. (2017). 5366 Sayllı Kanun Kapsamında Yenileme Alanlarında Gerçekleștirilen Kentsel Dönüşüm Süreci Üzerine Bir Deneme. Hacettepe Hukuk Fakültesi Dergisi, 7(2), 275-304.

Kocaoğlu, M. ve Sert, S. (2018). Kentsel Sürdürülebilirlik Kavramı Ve Kentsel Sürdürülebilirliğin Sağlanmasında Kent Konseylerinin Rolü Üzerine Bir Değerlendirme. Strategic Public Management Journal, 4(8), 52-61.

McPhearson, T., Iwaniec, D. M., ve Bai, X. (2016). Positive visions for guiding urban transformations toward sustainable futures. Current opinion in environmental sustainability, 22, 33-40.

Netcad Portal (01.07.2019). Erişim adresi http://portal.netcad.com.tr/pages/viewpage.ac tion?pageId=112787735 $\# 5$ d5a3ff753ef4ca $7 \mathrm{a} 9$ 8ef2f664f29aa1

Özbek, N. ve Uluoğlu, B. (2018). Geleneksel Konut Dokusunun Değiş̧im Süreci ve Sürdürülebilirliği. Yaşam Dünyası Bağlamında KastamonuKırkçeşme Caddesi'nin Analizi. tasarım+ kuram dergisi, 14(25), 78-100.

Özgür, T. ve Özgür, Ö. (2018). 6306 Sayll Kanun Çerçevesinde Kentsel Dönüşüm Uygulamalarının Mekansal Deneyimi: Ordu İli Örneği. ODÜ Sosyal Bilimler Araştırmaları Dergisi (ODÜSOBİAD), 8(1), 211-227.

Özyurt, G. ve Karabalı, K. (2009). Enerji verimliliği, binaların enerji performansı ve Türkiye'deki durum. TMMOB, İnşaat Mühendisleri Odası, Türkiye Mühendislik Haberleri, 457(54), 32-34. 
Parlak, B. (2018). Sürdürülebilir kalkınma ve kentli hakları perspektifinden kent kültürü ve kent kimliğinin dönüșümü: Bir proje örneği. TESAM Akademi, 11-48.

Rawluk, M. B. (2019). Advancing Boreal Forest Archaeology: Intrasite Spatial Analysis of the Eaglenest Portage Site (Doctoral dissertation, University of Saskatchewan).

Saatçi, M. ve Dumrul, Y. (2013). Elektrik tüketimi ve ekonomik büyüme ilişkisinin dinamik bir analizi: Türkiye örneği. Uludağ Üniversitesi İktisadi ve İdari Bilimler Fakültesi Dergisi, 32(2), 1-24.

Yomralığlu, T. (2013). Kentsel Dönüşüm için Coğrafi/Kent Bilgi Sistemleri. 1. Uluslararası Kentsel Dönüşüm Sempozyumu, 7-8 Ekim, Ankara.

Trencher, G. P., Yarime, M. ve Kharrazi, A. (2013). Cocreating sustainability: cross-sector university collaborations for driving sustainable urban transformations. Journal of Cleaner Production, 50, 40-55.

Turgay, T. (2018). Yeşil Tasarım ve Sürdürülebilir Mimari İle Kentsel Yenileme. İleri Teknoloji Bilimleri Dergisi, 7(2), 131-142.

Uğur, L. O., Aliefendioğlu, Y. ve Saka, M. (2016). Afet Riski Altındaki Alanların Dönüştürülmesi Hakkında Kanun'a göre riskli yapı tespitinde karşılaşılan uygulama problemlerinin vaka tabanlı incelenmesi: Tekirdağ ili örneği. Düzce Üniversitesi Bilim ve Teknoloji Dergisi, 4(1).

Uzgören, E. ve Özer, P. (2018). Avrupa Birliği Ülkelerinde Sanayi ve Konut Sektörü Elektrik Enerjisi Talebinin Fiyat Esnekliği Tahmini. Journal of Kastamonu University Faculty of Economics and Administrative Sciences, 20/4, 39, 58, 2.

Ülger, N. E. (2010). Türkiye' de arsa düzenlemeleri ve kentsel dönüşüm. Nobel Yayın Dağıtım.

Yalçın, G. ve Düzgün, H. Ş. (2013). Mekansal İstatistikte Nokta Deseni Analizi: Trafik Kazaları Analizi Örneği. TMMOB Harita ve Kadastro Mühendisleri Odası, 14. Türkiye Harita Bilimsel ve Teknik Kurultayı, 14-17 Mayıs 2013, Ankara.

Yenice, M. S. (2016). Türkiye'nin kentsel dönüşüm deneyiminin tarihsel analizi. Balıkesir Üniversitesi Fen Bilimleri Enstitüsü Dergisi, 16(1), 76-88. 